Jjpn. J. Hosp. Pharm.

$\left[\begin{array}{lll}21(6) & 502-505 & (1995)^{k}\end{array}\right]$

\title{
濁度变化を指標とした線溶醭活性の測定
}

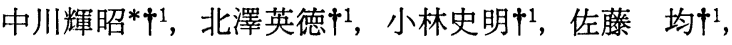

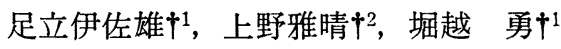 \\ 富山医科薬科大学附属病院薬剤部 $\dagger^{1}$ \\ 富山医科薬科大学薬学部 ${ }^{2}$
}

\section{Measurement of Fibrinolytic Enzyme Activity Using the Variation in Turbidity}

\author{
TERUAKI NAKAGAWA ${ }^{*} \uparrow^{1}$, HIDENORI KITAZAWA ${ }^{1}$, \\ FuMIAKI KOBAYASHI $\dagger^{1}$, HITOSHI SATOH $\dagger^{1}$, ISAO ADACHI ${ }^{1}$, \\ MASAHARU UENO ${ }^{2}$ and ISAMU HORIKOSHI ${ }^{1}$ \\ Department of Hospital Pharmacy $\dagger^{1}$, Faculty of Pharmaceutical Sciences $\dagger^{2}$, \\ Toyama Medical and Pharmaceutical University
}

$\left(\begin{array}{l}\text { Received January 24, } 1995 \\ \text { Accepted September 13, 1995 }\end{array}\right)$

The fibrinolytic activities of commercially available urokinase were compared using a platelet aggregometer, which is capable of measuring the change in turbidity during the fibrinogen dissolution process.

The fibrinolytic activities were evaluated from the half-lives of the turbidity ratio at $660 \mathrm{~nm}$ using fibrin as a plasmin substrate. A clear linear relationship was evidenced between the half-life of the turbidity ratio and fibrinolytic activity, conforming that this method is superior to others with regard to accuracy, sensitivity, reproducibility, and quickness of measurement.

Furthermore, no difference was seen between the fibrinolytic activities of two commercially urokinase preparations. In conclusion, the platelet aggregometer was found to be very useful devise for evaluating the fibrinolytic activity of urokinase.

Keywords-urokinase, turbidity, fibrinolytic activity, platelet aggregometer, plasmin

\section{は じめに}

線溶酵素剂として広く臨床で利用されているウ ロキナーゼは，ヒト尿中に多量に存在するセリン プロテアーゼの一種で, プラスミノーゲンを活性 化してプラスミンを生成する酵素であり，心笳梗 塞や血栓症の治療に汎用されてさた。

$\dagger^{1,2}$ 富山市杉谷 2630; 2630, Sugitani, Toyama, 930-01 Japan
ウロキナーゼの線溶活性测定法は，これまでに 試験管法 ${ }^{1)}$ ，フィブリン平板法 ${ }^{2)}$, チャンドラ・

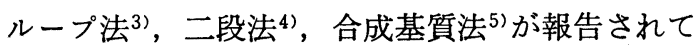
おり，更に著者らの開発したチャンドラ・ループ 変法6), トロンボェラストグラム法7), 微小熱量 計法8) などが知られている.

試験管法と二段法は, 検液中の気泡が消失する までの時間を測定する方法であり，フィブリン平 板法はフィブリン溶解空の面積から判定するが, 
これらの方法は試験管の直径・液量あるいはフィ ブリン平板の厚さ等に厳密な規定がなく, 主観の 入る余地が残されている. 合成基質法は, 感度は 優れているが，天然基質を用いていない。チャン ドラ・ループ法は, 未溶解の血栓の取り出しの操 作にバラッキの生じ易いことや，測定に時間のか かるのが欠点である. チャンドラ・ループ変法 は，これを改良し，新鮮血の代わりにフィブリ， ーゲンとトロンビンを用い，測定時間を短縮させ ている.トロンボェラストグラム法は，フィブリ ン形成のゲル化過程とフィブリン溶解のゾル化過 程での時間のズレを指標として線溶活性を測定す る方法である。また，微小熱量計法は，フィブリ ノーゲンが分解する際の熱的变化を指標としてい るが，フィブリンを用いていないことや，試料が 多量 $(4 \mathrm{ml})$ なことが欠点である.

本研究では, 天然の基質および血小板凝集メー タを用い, 試料は少量で, 短い時間内に線溶活性 を測定し得る方法がないかと検討したところ，興 味ある新しい方法を見出したので，以下にその詳 細を報告する。

\section{実 験 の 部}

\section{1. 試薬}

フィブリノーゲン; 凝固性蛋白 $1 \mathrm{~g} /$ 瓶(Lot No. 6750B), トロンビン; 500U/瓶(Lot No. 237), プラスミノーゲン; $1.5 \mathrm{mg} /$ 瓶 (Lot No. 006 $\mathrm{GN}$ ), プラスミン; $4.2 \mathrm{U} / \mathrm{mg}$ (Lot No. KU114 YU), ウロキナーゼミドリ 6000U/Vial (Lot No. $244 \mathrm{GN})$ はミドリ十字社の製品を用いた。 ウ ロキナーゼ 6000U/Vial (Lot No. 4B372) は持 田製薬の製品を用いた．塩化ナトリウム特級, EDTA，アラビアゴム，グルコース，イミダゾー ルは和光純薬の製品を用いた。

\section{2. フィブリン懸濁液の調製}

フィブリン懸濁液の調製は既存 ${ }^{9)}$ の調製方法に 準じた。すなわち，0.3\%の $\mathrm{NaCl}$ 溶液に溶解し た $3 \%$ ィブリノーゲン $33.3 \mathrm{ml}$ に同量の $0.3 \mathrm{M}$ $\mathrm{NaCl}$ および 2mM EDTA を含むトロンビン溶 液 (1.0unit $/ \mathrm{ml}$ ) を加え,フィブリン塊を形成さ せる. 次に蒸留水で十分洗浄後, $8 \mathrm{M}$ の尿素溶液
に溶解し，更に蒸留水 $\left(25^{\circ} \mathrm{C}\right)$ で十分透析する. 透析の終了したフィブリン懸濁液を加熱処理 $\left(60^{\circ}\right.$ C，30分間）してトロンビンを不活化した後， ア ラビアゴム拈よびグルコースをそれぞれ $1 \% ， 3$ \%になるように加え，超音波（強度10，20分間） 処理し，これに $100 \mathrm{mM} \mathrm{NaCl}$ を含む $50 \mathrm{mM}$ の イミダゾール（pH 7.5）〔最終濃度】を加え, 更 に10分間超音波処理する.

\section{3. 装置および原理}

二光バイオサイエンス社の 4 チャンネル自動血 小板凝集計（Model PAT-4A）を使用した。血 小板凝集計は図 1 に示すような構造をしており, $37^{\circ} \mathrm{C}$ 条件下で試料用セルにウロキナーゼとプラ スミノーゲンを注入しプラスミンを生成させた 後, フィブリン懸濁液を注入すると，フィブリン 塊がプラスミンによって溶解されるにつれて透過 率が増加する。フィブリン塊がすべて溶解されれ ば，最大の透過量を示すことになる．この透過率 の変化は, 光電密度として光電池で感知され, こ れを電圧に変え，增幅後，連続記録される。

\section{4. 測定方法}

血小板凝集計を用い, フィブリン懸濁液の濁度 を100\%,生食のそれを０\%に設定する.

(1) プラスミン活性測定

フィブリン懸濁液 $200 \mu \mathrm{l}$ を $37^{\circ} \mathrm{C}$ で 2 分間イン キュベートし，これにゲルろ過したプラスミン10 $\mu \mathrm{l}$ を各濃度 $(2.79,2.09,1.86,1.40,0.93$,

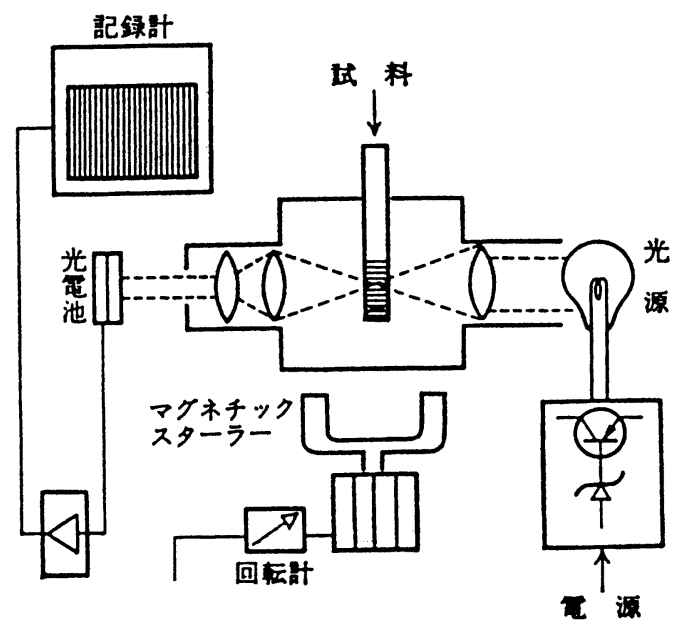

図 1. Platelet aggregometer の概略図 
$0.56,0.28,0.14) \mathrm{cu} / \mathrm{ml}$ で $37^{\circ} \mathrm{C}, 1$ 分間イン キュベートしたのち加え，透過率の変化を測定す る.

（2）ウロキナーゼ活性測定

$37^{\circ} \mathrm{C}$ 恒温下でプラスミノーゲン $(14 \mathrm{cu} / \mathrm{ml})$ $20 \mu \mathrm{l}$ にウ口キナーゼ $20 \mu \mathrm{l}$ を加之, 更に 1 分間イ ンキュベートする.これにフィブリン懸濁液 $200 \mu 1$ を加光, 透過率の変化を測定する.

\section{結果および考察}

天然の基質として用いたフィブリンの懸濁液 は，調製過程で尿素を添加するとフィブリノーゲ ンには影響せず，血液凝固第 XIII 因子のみを不活 化する ${ }^{10)}$ ので，この方法を利用した．この結果， フィブリンとプラスミンの反応が短時間に進み, 血小板凝集計の測定条件で分光光度計の測定と同 様の結果が得られた。

活性值既知のプラスミンを用い, 濁度が50\%に なる時間 $\left(\mathrm{T}_{1 / 2}\right)$ を測定し, 両対数グラフ上にプ ロットして図 2 に示す直線（検量線）を得た.

半減期法 ${ }^{11,12)}$ は, この検量線を利用するもので あり，直線については図 2 の相関係数 0.82 が得ら れたので，この直線を検量線として利用可能であ ることが確認できた.

そこで，この検量線を利用して，2 種のウロキ
ナーゼ製剤を種々の濃度に希釈し，50\%濁度を測 定し，図 3 の結果を得た。困 3 では，2 製品とも ウロキナーゼ濃度が $10 \sim 10^{3} \mathrm{unit} / \mathrm{ml}$ の範团で, $\log \mathrm{T}_{1 / 2}$ とウロキナーゼ活性の間に一次の直 線 関係が得られたことから，本法は臨床でも利用可 能なことがわかった。

図3によると，ウロキナーゼミドリはウロナー ゼよりもやや高い線溶活性を示したが，有意差は 認められなかった．本実験では 1 サンプルあたり 10分程度の時間で酵素活性を測定することが可能

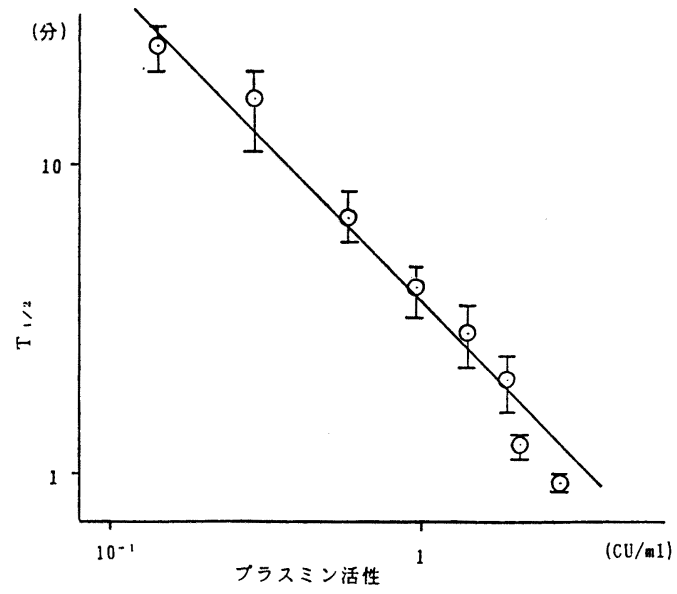

図 2. プラスミン活性と $50 \%$ 透過率に達する時間 $\left(T_{1 / 2}\right)$ との関係

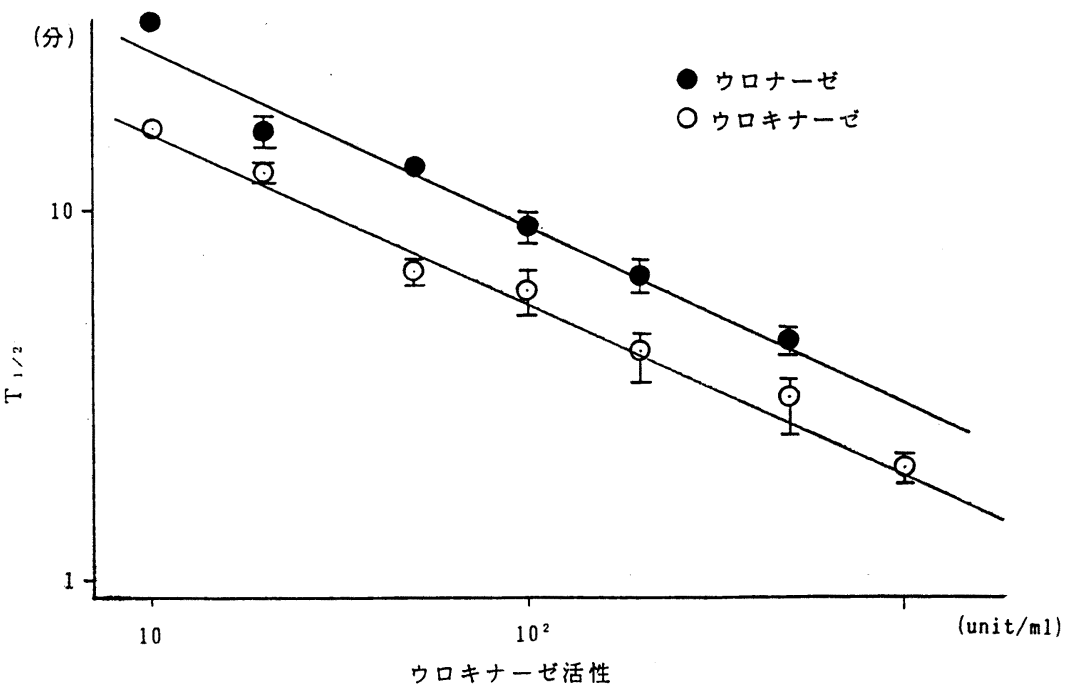

図 3. ウロキナーゼ活性と $50 \%$ 透過率に達する時間 $\left(\mathrm{T}_{1 / 2}\right)$ との関係 
なことがわかった.

ウロキナーゼ製剤より後発の組織プラスミノー ゲンアクチベータ（TPA）やウロキナーゼ前駆物 質 (Pro-UK) は，フィブリンに対する親和性が ウロキナーゼよりも高い.したがってそれらの活 性評価を行う際, 天然基質のフィブリンを使用し ている点で本法の有用性は高いと考えられる.

また，本法は他の方法に比へ測定時間が飛躍的 に短く手技が簡単で, 少量の試料で測定でき, 天 然の基質を用いており，総合的にみて従来の方法 より応用価値の高い測定方法である.

\section{引用文 献}

1）松岡松三, 桜川信男, 米山泰夫, 嶋岡 洵, 臨床 と研究，46，932-935 (1969).

2) N. Sakuragawa, M. Matsuoka, et al., Acta Med. Biol. (Niigata), 21, 1-11 (1973).

3) A. B. Chandler, Lab. Invest., 7, 110-114
(1958).

4) 山本博嗣, 田島英男, 酒巻道夫, J. Med. Enzymol., 1, 137-140 (1975).

5). Svendsen,L. et al., Thrombosis Research, 1, 267 (1972).

6）堀越 勇, 中川輝昭, 今村曜子, 宮崎博子, 高橋 董, 桜川信男, 病院薬学, 7(2). 123-127(1981).

7) 中川輝昭, 安田晶子, 鳥居塚和生, 上野雅晴, 堀 越 勇, 病院薬学, 12(5), 369-372 (1986).

8) 中川輝昭, 川端奈緒美, 足立伊佐雄, 上野雅晴, 堀越 勇, 病院薬学, 16(3), 185-188 (1990).

9）金井正三, 岡本 寛, 玉浦 裕, 稲田裕二, 血液 と脈管, 11(1), 62-65 (1980).

10）三輪史朗，“臨床検査技術全書 3 (血液検査)”, 医学書院, 東京, 1978, p.511.

11）宮嶋孝一郎, “医薬品の開発15巻”, 廣川書店, 東 京, 1989, p.136-140.

12) 後藤 茂, “医薬品の開発16巻”, 廣川書店, 東 京, 1990, p.156-175. 